\title{
PENGARUH ELEMEN-ELEMEN RANCANG KOTA DI KAWASAN JALAN GAJAH MADA DENPASAR BALI
}

\author{
I Made Agus Mahendra
}

Univeritas Mahendradata

\begin{abstract}
Elemen-elemen rancang kota merupakan bagian-bagian yang membentuk karakteristik kawasan. Elemenelemen rancang kota dapat dikategorokan berdasarkan jenis, bentuk, ukuran,sifat, hingga pada penggunannya. Elemen rancang kota pada umumnya dibagi berdasarkan sifatnya yaitu elemen rancang kota bersifat fisik maupun elemen rancang kota bersifat aktivitas. Elemen fisik rancang kota cenderung bersifat ragawi (tangible) dan elemen aktivitas cenderung bersiat non-ragawi (intangible)

Kawasan Jalan Gajah Mada di Denpasar merupakan kawasan pusat kota yang padat dalam kapasitas penghuni dan pengguna jalan. Sehingga menimbulkan berbagai masalah berupa kemacetan dan tingkat polusi yang tinggi. Ditambah dengan kurang tertatanya tata hijau dalam kawasan dan peraturan bangunan setempat yang dilanggar. Sehingga ruang jalan dalam kawasan perlu dihijaukan karena fungsi ruang jalan sangat vital dan tidak dapat berubah maka penataan tata hijau perlu ditinjau kembali.

Tujuan dari penelitian ini adalah mengetahui dan menemukan pengaruh elemen fisik terhadap elemen aktivitas pada "kehidupan" fungsi kawasan Jalan Gajah Mada Denpasar serta memberikan arahan penataan pada elemen fisik dan aktivitas yang dapat menghidupkan kawasan

Penelitian ini menggunakan pendekatan rasionalistik dengan data yang diolah secara kualitatif. Data berupa literatur dan peta dikumpulkan untuk melihat tanda-tanda dan temuan di lapangan. Kemudian menyusun konsepsualisasi teoritik berdasarkan teori-ᄀteori yang ada dari variabel penelitian.Dalam penelitian ini juga dilakukan proses Metode Analisa deduksi yaitu usaha menjelaskan atau meramalkan tentang adanya fakta/ kejadian di lokasi penelitian menurut landasan teori yang sudah diperoleh.

Temuan penelitian menunjukkan bahwa pada penggal amatan pertama dan ketiga sudah memiliki tata vegetasi yang baik pada sisi sebelah timur, terlihat dari jenis, fungsi, tajuk dan ketinggian, serta ketersediaan lahan yang baik serta memenuhi peraturan bangunan setempat. Dan pada penggal amatan kedua memiliki tata vegetasi yang kurang, dikarenakan tidak adanya ketersediaan lahan yang baik pada kedua sisi, serta tata vegetasi kurang terlihat dari jenis, fungsi, tajuk dan ketinggiannya.
\end{abstract}

Kata Kunci: elemen fisik kawasan, elemen aktivitas kawasan, rancang kota

\section{Pendahuluan}

Pada umumnya di Asia Tenggara, kita dapat melihat bahwa perkembangan kota-kota modern banyak dibentuk berdasarkan warisan sejarah masa sebelumnya. Dalam kajian tentang masalah perkotaan, beberapa aspek penting yang memainkan peranan penting adalah keadaan demografi, teknologi, organisas aktivitas, dan lingkungan. Dengan demikian aspek-aspek itu penting untuk dipahami, karena adanya faktor yang saling kait mengkait Dalam dinamika sejarahnya, banyak kota-kota itu terlahir sebagai akibat pusatpusat politik tradisional seperti pusat-pusat istana kerajaan, pusat-pusat perkembangan perdagangan

Pembangunan lingkungan fisik kota merupakan suatu usaha manusia untuk meningkatkan kualitas lingkungan sehingga dapat meningkatkan kinerja manusia dalam melaksanakan kegiatannya. Pembangunan fisik kawasan kota tidak dapat dilepaskan dari kebutuhan manusia sebagai pelaku utama kegiatan di kota. Pola ruang kota dan komponen fisik pembentuknya dapat mencerminkan adanya pertumbuhan dan perkembangan temporal lingkungannya. komunitas. Dengan demikian tumbuh dan berkembangnya tuntutan-tuntutan pelaku kegiatan. Berarti secara fisik dan fungsional intensitas dan kualitas kegiatan kota akan selalu berubah.Sebuah kota terbentuk karena adanya interaksi kegiatan manusia dalam menjalani kehidupan dan penghidupannya ini terbentuk karena adanya fungsi

Kawasan Jalan Gajah Mada pada saat ini, kawasan ini menyimpan berbagai potensi yang akan memberikan banyak kontribusi dan efek positif dalam penataan kawasan dan kehidupan seluruh masyarakat. Berbagai potensi tersebut seperti keberadaan Pasar Tradisional Badung dan Pasar Seni Kumbasari, maupun deretan pertokoan sepanjang koridor ini merupakan sentral bisnis yang sangat potensial untuk peningkatan fungsi kawasan Keberadaan Pura Desa Adat Denpasar sebagai Eksistensi Arsitektur Bali tidak bias dilepaskan dari akar dasar pertumbuhan dan perkembangan arsitektur bali tradisional, yang mempunyai kearifan lokal dengan kandungan makna serta nilainilai filosofis, humanis dan ekologis. Sesungguhnya, dalam tata ruang arsitektur bali mengalir nafas spiritualitas, moralitas dan keharmonisan dan keselarasan dengan alam dan lingkungannya. tg Lapangan Puputan Badung yang berbaur dengan kegiatan bisnis merupakan pencampuran fungsi kawasan yang menarik. 
Permasalahan yang terjadi di kawasan jalan Gajah Mada Denpasar bali dapat diamati pada konteks Keberlanjutan pembangunan baik dari sisi lingkungan, sosial maupun Ekonomi Keberadaan dari elemen fisik Elemen-elemen street furniture, vegetasi yang kurang dan sangat minim sebagai faktor yang dapat mendukung keberlanjutan ekonomi sebagai sebuah kawasan komersial dan budaya. Pada elemen aktivitasnya Keberlanjutan Bangunan yang fungsinya 'mati' terkonsentrasi pada lokasi tertentu dan Kurang optimalnya dan tidak seimbangnya penggunaan/ fungsi kawasan. Berdasarkan rumusan permasalahan tersebut dapat ditarik dua poin pertanyaan penelitian yaitu :

1. Bagaimanakah pengaruh elemen fisik terhadap elemen aktivitas pada "daya hidup" kawasan Jalan Gajah mada Denpasar?

2. Bagaimanakah arahan Penataan pada elemen fisik dan aktivitas yang dapat menghidupkan kawasan Jalan Gajah Mada Denpasar?

Tujuan dari penelitian pengaruh elemen fisik terhadap elemen aktivitas pada kehidupan fungsi kawasan ini yaitu :

1. Mengetahui dan menemukan pengaruh elemen fisik terhadap elemen aktivitas pada " daya hidup " fungsi kawasan Jalan Gajah mada Denpasar

2. Memberikan Guideline dan arahan Penataan pada elemen fisik dan aktivitas yang dapat menghidupkan kawasan Jalan Gajah Mada Denpasar, Bali

Tabel 1. Keaslian Penulisan

\begin{tabular}{|c|c|c|c|}
\hline NO & PENELITI & JUDUL & LOCUS \\
\hline 1. & Anfin:2003 & $\begin{array}{l}\text { Ruang Jatan Sebagai fuang } \\
\text { pubik di kawasan korrersial }\end{array}$ & $\begin{array}{l}\text { Jalan Pemuda } \\
\text { Magelang }\end{array}$ \\
\hline 2. & $\begin{array}{l}\text { Firi Whandarl } \\
2005\end{array}$ & $\begin{array}{l}\text { Seting Elemen fisk dint ahtivizas } \\
\text { pada pengguna }\end{array}$ & $\begin{array}{l}\text { In dr Ralman, } \\
\text { coyudan solo }\end{array}$ \\
\hline 3. & $\begin{array}{l}\text { Morfosa Meiry, } \\
2002\end{array}$ & $\begin{array}{l}\text { Konfik Kepentingan yang terjadi } \\
\text { di jatur Pedestrian }\end{array}$ & $\begin{array}{l}\text { Simpeng empat sini } \\
\text { sono-yogyakara }\end{array}$ \\
\hline 4. & $\begin{array}{l}\text { Purwanto W } \\
2001\end{array}$ & $\begin{array}{l}\text { Pemantaatan Ruvang tortuka } \\
\text { pobtik ditinjau dori aspok } \\
\text { linghungan priaku }\end{array}$ & $\begin{array}{l}\text { Jaba A Yani } \\
\text { Wonosobo }\end{array}$ \\
\hline
\end{tabular}

\section{Tinjauan Pustaka}

\section{Konsep Tata Ruang Budaya Bali}

Nilai-nilai luhur budaya Bali, yaitu hal-hal yang dianggap baik dan berharga dalam Keberlanjutan daya hidup masyarakat dan kebudayaan mencakup satu rentangan unsur-unsur abstrak (intangible culture, unsur budaya tak benda) yang terdiri dari unsur filosofis, unsur nilai, unsur konsep dan unsur norma aturan

Ruang

Ruang merupakan wadah atau elemen fisik yang dapat mempengaruhi pelaku atau pengguna. Pengertian ruang itu sendiri adalah sistem lingkungan binaan terkecil di mana sebagian besar waktu manusia di habiskan di dalamnya. Ruang tidak dapat dipisahkan dari manusia baik secara psikologis, emosional, maupun dimensional.

\section{Elemen}

Elemen ialah interaksi antara lingkungan sebagai media beraktivitas dengan manusia sebagai penggunanya. Elemen, melihat keterkaitan antara elemen-elemen fisik lingkungan dengan kegiatan manusia (publik) dalam kerangka waktu tertentu Elemen ruang jalan, yaitu melihat kaitan antara fisik ruang (dinding dan ruang jalan), instalasi elemenelemen dalam ruang jalan, dan aktivitas pengguna (dengan segala prasyarat kebutuhannya - fisioiogis /psikologis) dan Street wall

\section{Livable City}

Livability mengacu pada sistem perkotaan yang memberikan kontribusi untuk fisik, sosial dan mental untuk kesejahteraan dan pengembangan masyarakatnya. Ini adalah tentang kenyamanan yang diinginkan yang menawarkan ruang-ruang perkotaan dan mencerminkan budaya

\section{Landasan Teori}

Landasan teori yang diambil pada penelitian ini mencakup tentang ruang, elemen elemen-elemen perkotaan dan daya hidup kota yang melingkupi suatu kawasan kota, khususnya koridor ruang jalan. Landasan teori ini digunakan dalam membuat variabel penelitian yang nantinya digunakan sebagai acuan dalam meneliti dan analisis pembahasan serta saat menemukan temuan-temuan pada saat penelitian berlangsung

\section{Metode Penelitian}

\section{Paradigma dan Metode}

Penelitian ini menggunakan pendekatan rasionalistik dengan data yang diolah secara kualitatif. Data berupa literatur dan peta dikumpulkan untuk melihat tanda-tanda dan temuan di lapangan. Kemudian menyusun konsepsualisasi teoritik berdasarkan teori-teori yang ada dari variabel penelitian.

Dalam penelitian ini juga dilakukan proses Metode Analisa deduksi yaitu usaha menjelaskan atau meramalkan tentang adanya fakta/ kejadian di lokasi penelitian menurut landasan teori yang sudah diperoleh. Ini juga digunakan untuk menyusun konseptualisasi teoritik untuk melihat kesatuan holistik permasalahaan yang ada pada kawasan Jalan Gajah mada denpasar

\section{Lingkup dan Wilayah Penelitian}

a. Studi awal dan analisa akan melakukan identifikasi terhadap elemen fisik dan aktivitas di kawasan jalan Gajah mada denpasar dan pengaruh dari elemen fisik terhadap elemen tahapan ini dilakukan untuk memetakan dan dapat mengetahui 
bentuk-bentuk dan kegiatan yang dilakukan oleh masyarakat serta dapat mengkaitkan

b. Faktor-faktor yang berpengaruh terhadap "daya hidup fungsi kawasan. setelah mendapatkan faktor-faktor yang berpengaruh terhadap daya hidup fungsi kawasan. barulah dikaji dengan variable dari sustainable urban form sehingga nantinya dapat memberikan guidline yang tepat terhadap kawasan

\section{Lokasi Penelitian}

Secara geografis kawasan studi terletak antara $8^{\circ} 18^{\prime} 52^{\prime \prime}-8^{\circ} 37^{\prime} 50^{\prime \prime}$ Lintang Selatan dan $115^{\circ} 05^{\prime} 29^{\prime \prime}-115^{\circ} 22^{\prime} 23^{\prime \prime}$ Bujur Timur, yaitu terletak disepanjang koridor Jalan Gajah Mada di Denpasar dengan batas timur adalah patung Catur Muka dan batas barat adalah Pertigaan Jalan Gajah Mada dengan Jalan Thamrin Secara administratif batasan kawasan perencanaan ada di Kecamatan Denpasar Barat ada 2 (dua) desa/kelurahan yaitu Kelurahan Pamecutan, dan Desa Dauh Puri Kangin, dan di Kecamatan Denpasar Utara ada 2 (dua) desa yaitu Desa Pamecutan Kaja, Desa Dauh Puri Kaja

\section{Mekanisme Penelitian}

\section{a. Persiapan penelitian}

Persiapan penelitian sebagai awal adalah mengenali permasalahan di lapangan, menentukan variabel penelitian, mengumpulkan data, dan mengkategorisasikan data berdasarkan variabel. Dalam persiapan ini dilakukan pemetaan fisik pada peta dasar berdasarkan elemen fisik yang ada

b. Teknik pengambilan data Penelitian

Penelitian membutuhkan kegiatan pendataan yang sesuai dengan kenyataan di lapangan. Pendataan yang dilakukan secara akurat akan di dapat penilaian yang objektif.

- Data primer diperoleh melalui,

Pengamatan terhadap variabel-variabel dari elemen aktivitas yang terjadi dan elemen fisik beserta elemen- elemen pendukung yang terdapat di lokasi amatan, mulai dari keseluruhan kawasan, segmen-segmen penggal jalan per zona kawasan fungsi dilakukan dengan cara wawancara langsung kepada pemakai/ pengguna jalan

- Data sekunder diperoleh melalui

Peta-peta dasar bangunan, peta garis, site plan dan block plan serta peta wilayah studi yang berkaitan

\section{c. Pelaksanaan penelitian}

Pelaksanaan penelitian dilakukan dengan langkah-langkah pengambilan data di lapangan yaitu :

- Mengidentifikasi elemen-elemen fisik dalam bentuk, peletakan, fungsi dan kondisi. Mengolah keterkaitan antara fisik dan aktivitas
- Mengidentifikasi pelaku pengguna ruang dan pemanfaatan ruangnya berdasarkan kelompok pelaku dalam pemetaan

- Menentukan temuan masalah dari fenomena lapangan dan berusaha mengarah pada pemecahan pertanyaan penelitian melalui analisis dan konsep penelitian

- Wawancara sebagai pendukung data dan tambahan informasi terhadap pelaku kegiatan dan penggunaan ruang

\section{d. Analisis Data Penelitian}

Tahap pertama, analisa dilakukan secara induktif, yaitu data yang diperoleh dari hasil pengamatan dilapangan dan wawancara pada kasus demi kasus dikumpulkan dan dikelompokkan sesuai dengan karakteristiknya

- Pengelompokan atau pengkategorisasian waktu pemanfaatan ruang dari data yang dihasilkan

- Pengelompokan atau pengkategorisasian ruang dari data yang dihasilkan

- Pengelompokan atau pengkategorisasian aktivitas yang dilakukan oleh pengguna ruang di lingkungan fisiknya

Tahap kedua, analisis dilakukan secara deduktif. Analisis diawali dengan mencari atau melihat adanya hubungan antara sub kategori yang telah dirumuskan

- Melihat hubungan dengan kategori yang merupakan hasil interaksi antara pemanfaatan ruang, kegiatan makro. Building use, dalam prosentase

- Mendeskripsikan dari hasil pengelompokkan dan hubungan antara kategori tersebut serta perolehan prosentase Hubungan tersebut diperlukan untuk menjelaskan kecenderungan yang terjadi akibat adanya keterkaitan terhadap unsur- unsur yang terkandung dalam faktor penentu.

e. Kesimpulan dan Rekomendasi

Hasil keseluruhan analisis dan pembahasan serta temuan-temuan yang ada dilapangan kemudian disimpulkan dan digunakan sebagai dasar rnembuat rekomendasi yang dapat dipakai dalam upaya perencanaan kawasan koridor jalan Gajah Mada Denpasar, bali yang berkaitan dengan elemen elemen fisik dan aktivitas pada daya hidup fungsi kawasan

\section{Hasil Penelitian dan Pembahasan}

Pada identifikasi elemen ruang jalan ini akan dikelompokkan dalam dua bagian yaitu identifikasi elemen fisik dan elemen aktivitas (Rapoport,1982), pembahasan elemen ini merupakan hasil analisis pengamatan terhadap elemen fisik dan elemen aktivitas yang terdapat di ruang jalan kawasan Gajah mada Denpasar yang di bagi menjadi tiga zona amatan, yaitu zona komersial I, komersial II dan zona budaya 
Dimana Pada kawasan Gajah mada ini pada Elemen Fisik dan Aktivitasnya sangat berpengaruh terhadap perkembangan dari kawasan tersebut, sangat berkaitan dengan konsep-konsep dan teoriteori dari budaya bali dan agama hindu, disamping dengan mengkaitkannya dengan teori-teori yang lepas dari kaca mata teori-teori setempat. di mana dari temuan-temuan yang ada di lapangan akan dikaitkan dengan sebab dan akibat yang ditimbulkan oleh elemen fisik dan aktivitas yang terjadi, dan penemuan faktor-faktor yang dapat mempengaruhi 'daya hidup' fungsi kawasan tersebut. pengkajian dari Sustainable Urban form terhadap faktor-faktor yang berpengaruh terhadap 'daya hidup fungsi kawasan sangat berkaitan dengan konsep-konsep dan teori-teori dari budaya bali dan agama hindu, disamping dengan mengkaitkannya dengan teori-teori yang lepas dari kaca mata teori-teori setempat.

Pada analisis elemen aktivitas ini melibatkan keseluruhan aktivitas yang terjadi pada ruang jalan baik bersifat dinamis maupun statis, dari elemen aktivitas pada kawasan jalan Gajah mada elemen dari elemen aktivitas yang dikaji:

1. PKL

2. Budaya

3. Pejalan kaki

4. Parkir

5. Pengguna kendaraan

Pada analisis elemen fisik ini melibatkan keseluruhan ruang lingkup fisik yang berada pada kawasan Jalan Gajah Mada, dari elemen fisik pada kawasan jalan Gajah mada elemen dari elemen fisik yang dikaji adalah :

1. Bangunan

2. Street Furniture

3. Pedestrian

4. Vegetasi

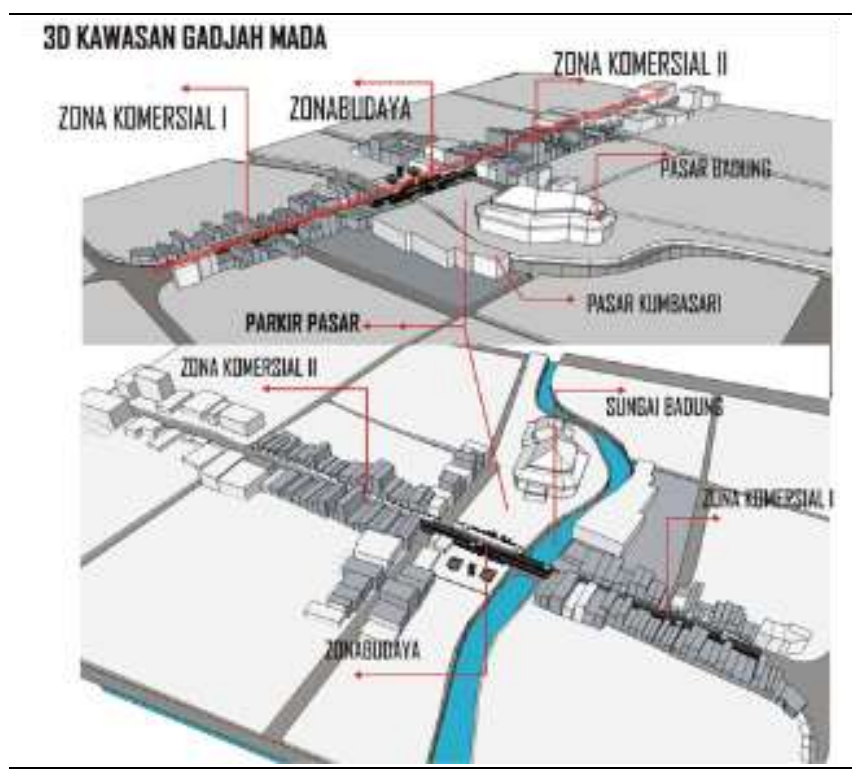

Gambar 1. 3D Kawasan Gajah Mada
1. Pengaruh dan Hubungan Antara Elemen Fisik dan Aktivitas

Dari kajian elemen fisik dan aktivitas yang telah dianalisis, sehingga di dapat pengaruh yang terjadi antara elemen fisik dan aktivitas

a. Penggal 1 Kawasan Zona Komersial I

- Bangunan dengan fungsi magnet dan komoditas menarik yang memiliki fasad teratur aktivitasnya banyak dikunjungi oleh pejalan kaki(pengunjung)

- Street furniture pada kawasan zona komersial ini sangat minim sehingga tidak memberikan kontribusi kepada fungsi bangunan sebagai elemen pendukung aktivitas pada fungsifungsi bangunan

- Kenyamanan pada kawasan komersial ini sangat kurang di mana elemen street furniture yang ada pada kawasan ini seperti. Lampu jalan, tempat duduk, toilet umum, dan pagar pengaman tidak ada dan sangat minim, street furniture merupakan elemen kawasan yang sangat berpengaruh terhadap aktivitas

- Dari aktivitas pejalan kaki pada kawasan ini, di mana jenis pedestrian yang ada pada zona komersial ini adalah pedestrian arcade dimana memberikan akses langsung kepada fungsi bangunan dan aktivitas pejalan kaki pada kawsan ini menjadi lebih nyaman karena terlindung dari panasnya sinar matahari

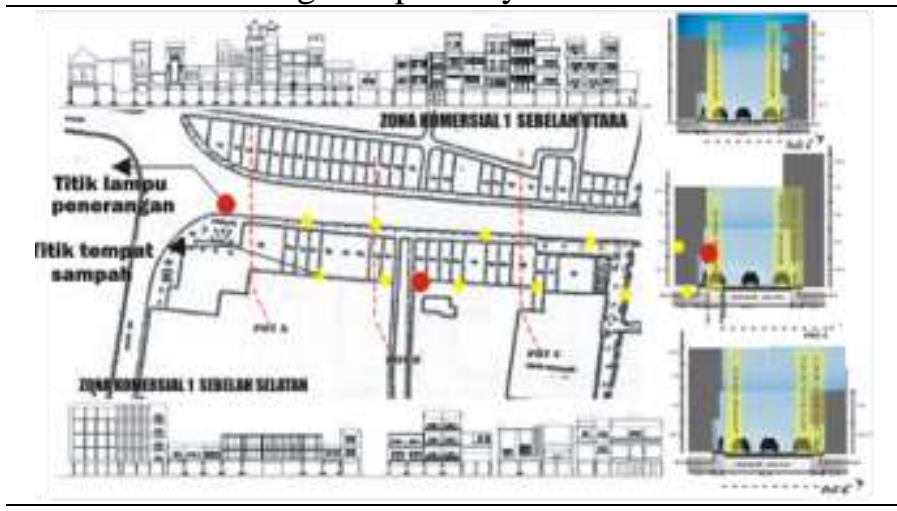

Gambar 2.

- Aktivitas parkir pada kawasan ini juga sangat membutuhkan lampu jalan sebagai elemen street furniture yang berfungsi sebagai penerang pada aktivitas jalan pada ruang jalan

- Dari vegetasi pengaruh terhadap aktivitas yang ada pada penggal 1 zona komersial tidak terlalu berdampak signifikan karena aktivitas PKL yang berada pada ruang jalan pada zona ini dilakukan pada malam hari

\section{Penggal 1 Kawasan Komersil \\ Elemen Fisik Kawasan \\ Bangunan \\ Pada kawasan zona komersial I, tidak mempunyai setback bangunan, yang langsung berbalasan dengan badan jalan}




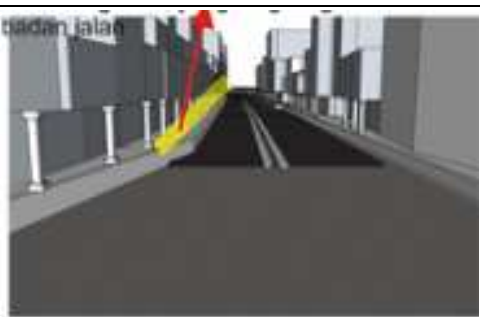

Gambar 3.

\section{Bangunan}

Pada setiap bangunan zona komersil I memiliki kolom dan pot pohon yang berada di jalur pedestrian Arcade disepanjang kawasan
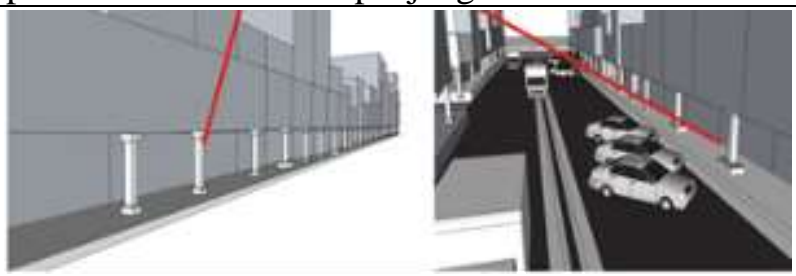

Gambar 4.

Aktivitas yang terjadi akibat elemen fisik bangunan berupa tidak adanya setback bangunan ppada kawasan ini, dimana aktivitas yang terjadi pada ruang jalan terdapat PKL sesaji dan janur yang memanfaatkan ruang jalan sebagai tempat untuk berjualan dan terjadinya on street parking pada ruang jalan

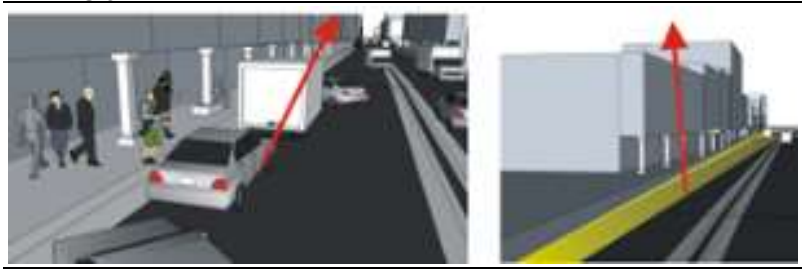

Gambar 5 .

Aktivitas yang terjadi, di mana para pemilik toko, memanfaatkan kolom pada bangunan sebagai display barang dagangannnya, dan tempat pot yang tersedia digunakan sebagai tempat duduk-duduk oleh para pegawai toko sisamping sebagai display barang dagangan juga.

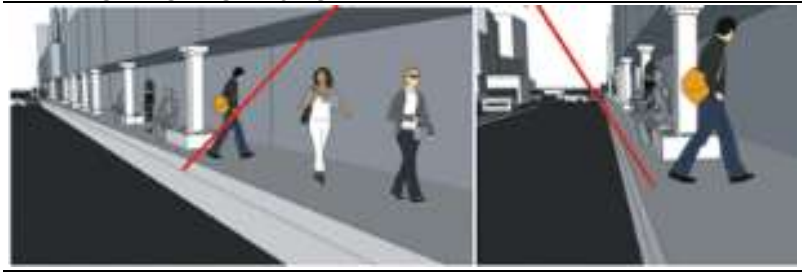

Gambar 6.

Street furniture yang berua lampu jalan yang perletakan pada zona komersial I sangat jarang dan berkisar 10-15 meter serta perletakannya tidak beraturan.

Dari stting fisik street furniture yang berupa tempat samppah dari tiap-tiap bangunan dan penggal kawasan tempat sampah hanya terdapat 10 buah.
Jalur pedestrian yang berupa arcade dan dengan lebar pedestrian 1,2 meter, kondisi dari permukaan setiap jalur pedestrian di depan toko berbeda ketinggian dengan setiap toko men-display barang dagangannya pada depan sisi toko tepat pada jalur pedestrian arcade.
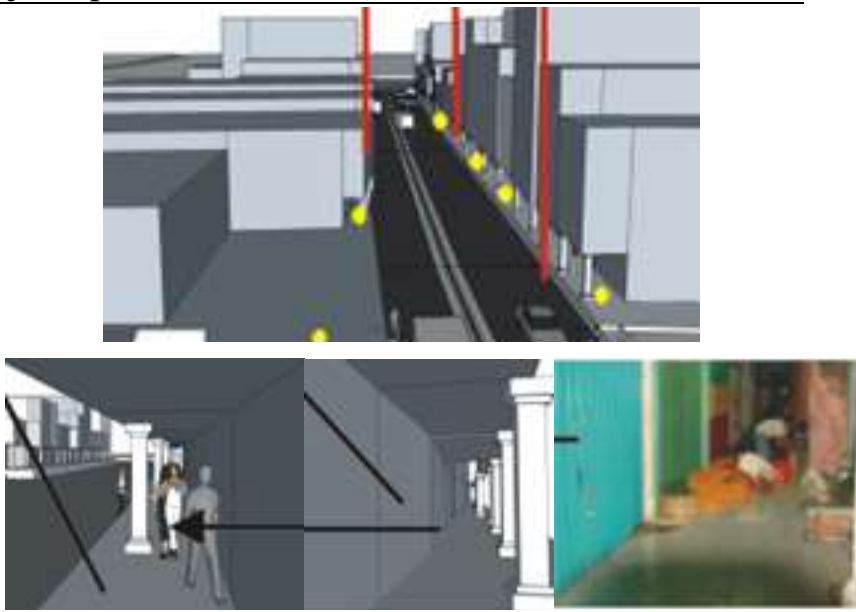

Gambar 7.

Penggal 2 Kawasan budaya

Pada zona budaya sebelah selatan set back bangunan berjarak $4.5 \mathrm{~m}$, dengan ruang yang lebar aktivitas yang terjadi pada ruang ini adalah para PKL memanfaatkan ruang ini sebagai tempat berjualan sesaji, makanan dan sebagai drop zone bagi para pedagang yang berdagang di pasar badung

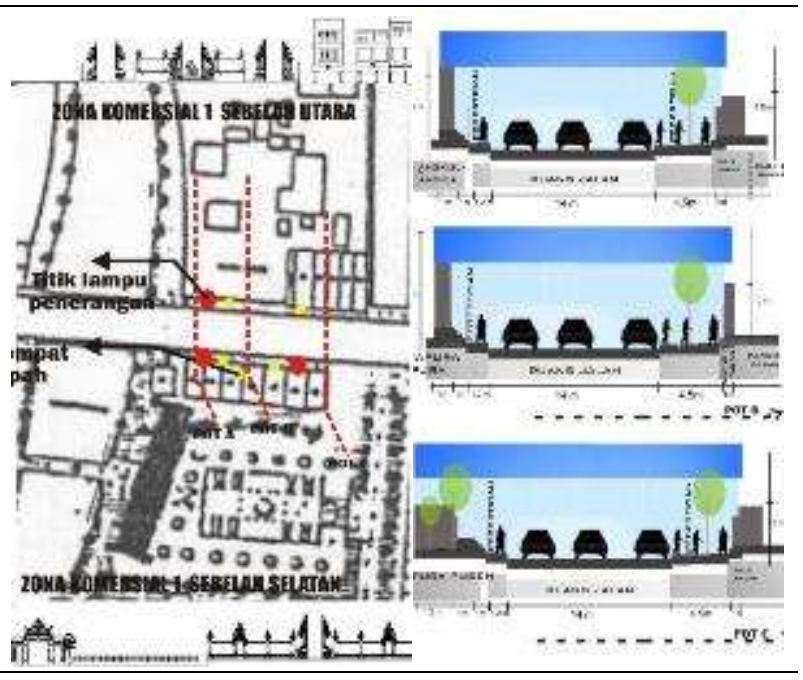

Gambar 8 .

Elemen Fisik Kawasan

Aktivitas pada kawasan budaya ini bergulir hampir 24 jam ini disebabkan oleh pengaruh dari pasar badung yang berada di selatan zona ini yang pada malam harinya pasar badung itu tutup dengan sendirinya kawasan disekitar ruang jalan akan ramai dipenuhi oleh para PKL

Terdapat ppasar badung dan area parkir pada zona budaya sebelah selatan ruang jalan

Jalur Pedestrian 


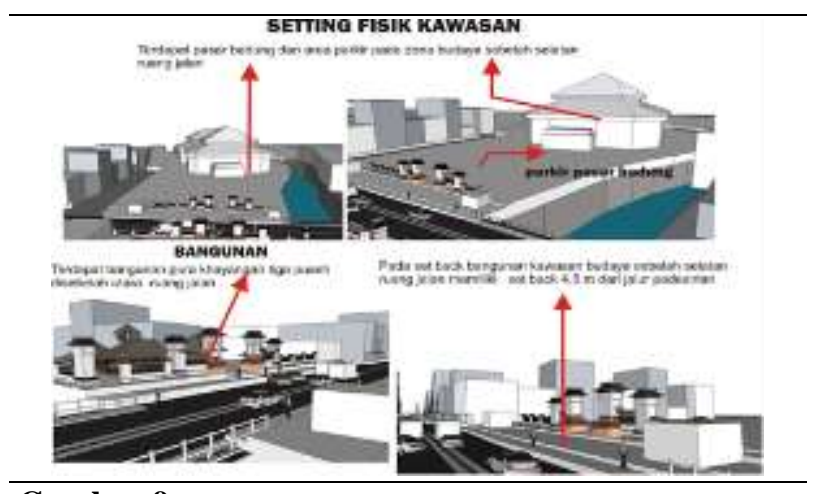

Gambar 9.

Bangunan

Terdapat bangunan pura "Kahyangan Tiga: Pusaeh "disebelah utara ruang jalan

Pada Setback bangunan kawasan budaya sebelah selatan ruang jalan memiliki setback 4,5 meter dari jalur pedestrian

\section{Elemen Aktivitas Kawasan}

1. Pada kawasan budaya kebutuhan fisik street furniture sangat tinggi dan sangat mempengaruhi dari umat beragama untuk melakukan persembahyangan, dari lampu penerangan jalan, tempat sampah sampai tempat duduk

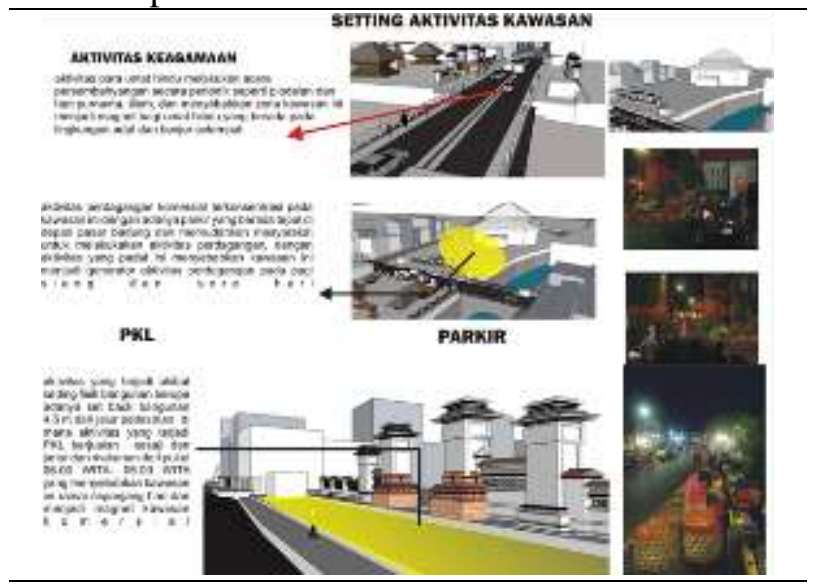

\section{Gambar 10.}

Aktivitas Keagamaan

Aktivitas para umat Hindu melakukan acara persembahyangan secara periodik seperti piodalan dan hari purnama, tilem dan menyebabkan zona kawasan ini menjadi magnet bagi umat Hindu yang berada pada lingkungan adat dan banjar setempat

\section{Aktivitas Perdagangan}

Aktivitas perdagangan komersial terkonsentrasi pada kawasan ini dengan adanya parkir yang berada tepat di depan pasar badung dan memudahkan masyarakat untuk melakukan aktivitas perdagangan, dengan aktivitas yang padat ini menyebabkan kawasan ini menjadi generator aktivitas perdagangan pada pagi, siang dan sore hari

\section{PKL}

Aktivitas yang terjadi akibat elemen fisik bangunan berupa adanya setback bangunan 4,5 meter dari jalur pedestrian dimana aktivitaas yang terjadi PKL berjualan sesaji dan janurr serta makanan dari pukul 06.00 WITA - 06.00 WITA yag menyebabkan kawasan ini ramai sepanjang hari dan menjadi magnet kawasan komersial.

2. Pedestrian area sangat memberikan aksesibilitas yang mudah bagi umat beragama menuju tempat persembahyangan

3. Dari vegetasi pada zona budaya terdapat pohon beringin 2 buah yang besar, dimana aktivitas para Pkl terkonsentrasi pada Pohon-Pohon Besar, disamping memberi keteduhan dan juga kenyamanan pada saat berjualan dan juga kenyamanan bagi para pejalan kaki, Pembeli

4. Pengaruh on street parking pada kawasan zona budaya ini sangat besar, di mana pada pura kelihatan tidak menarik dan menyebabkan konflik antara pengguna jalan yang melintas dan para umat hindu yang akan melakukan persembahyangan di pura dan menyebabkan kemacetan pada ruas jalan Gajah Mada

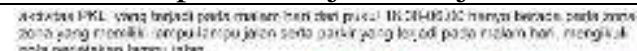

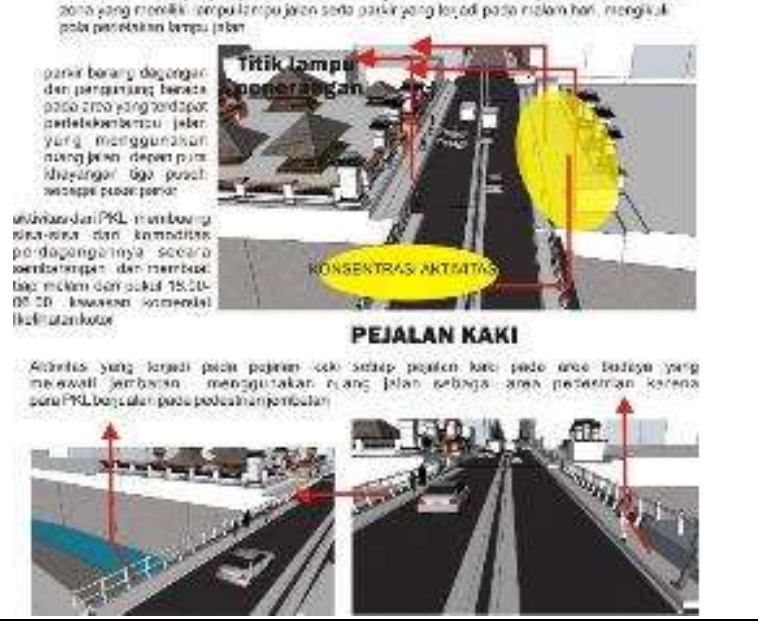

Gambar 11.

Aktivitas PKL yang terjadi ppada malam hari yang terjadi dari pukul 18.00 WITA - 06.00 WITA hanya berada pada zona-zona yang memiliki lampu jalan serta parkir yyang terjadi pada malam hari mengikuti pola perletakan lampu jalan umum.

Parkir barang dagangan dan pengunjung berada pada area yang terdapat perletakan lampu jalan yang menggunakan ruang jalan depan Pura Kahyangan Tiga Puseh sebagai pusat parkir

Aktivitas dari PKL membuang sisa-sisa dari komoditas perdagangannya secara sembarangan dan membuat tiap malam dari pukul 18.00 WITA06.00 WITA kawasan komersil terlihat kotor

Aktivitas yang terjadi pada pejalan kaki setiap pejalan kaki pada area budaya yang melewati jembatan menggunakan ruang jalan sebagai area pedestrian karena para PKL berjualan pada pedestrian jembatan

\section{Penggal 3 Kawasan komersial II}

1. komoditas yang mudah dikenali oleh pengunjung oleh sebab itu para pemilik toko lebih mendisplay barang dagangannya disekitar jalur pedestrian 
2. Street furniture yang ada pada kawasan zona komersial ini sangat minim terutama kursi dan lampu penerangan jalan pada malam hari sehingga tidak memberikan suatu kenyamanan bagi pejalan kaki melewati kawasan komersial ini.aktivitas yang berlangsung dan padat hanya berada pada titik-titik spot yang memiliki penerangan jalan dan tempat yang nyaman

3. Hal tersebut menyebabkan kontribusi kepada fungsi kawasan sebagai elemen pendukung aktivitas pada fungsi- fungsi bangunan sangat kurang karena tidak adanya lampu penerangan jalan

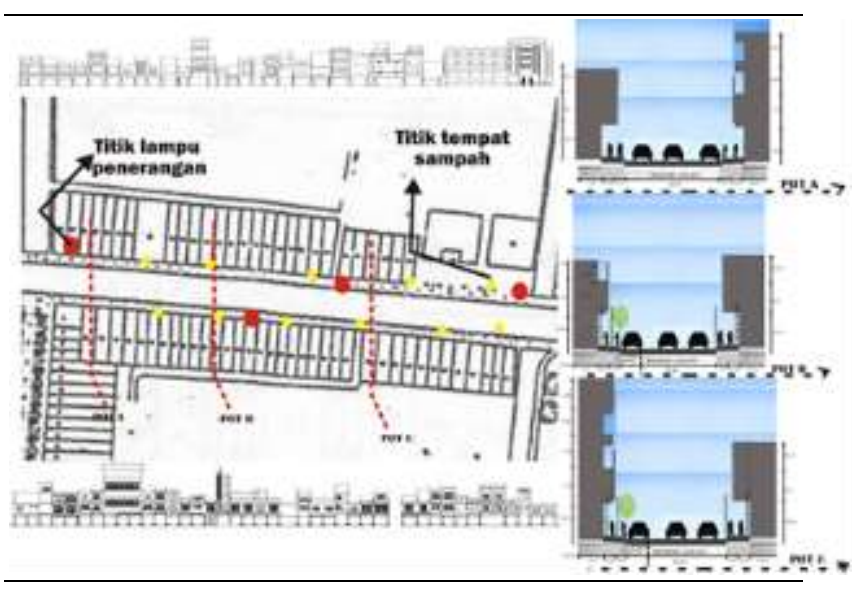

Gambar 12.

Aktivitas yang terjadi akibat elemen isik bangunan berupa tidak adanya setback bangunan pada kawasan ini, dimana aktivitas yyang terjadi pada ruang jalan terdapat PKL sesaji dan janur yang memanfaatkan ruang jalan sebagai tempat untuk berjualan dan terjadinya on street parking pada ruang jalan

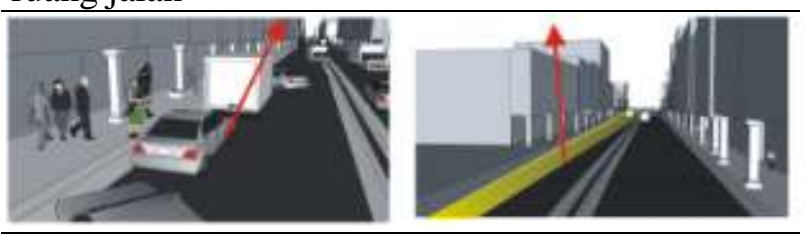

Gambar 13.

Aktivitas yang terjadi dimana para pemilik toko memanfaatkan kolom pada bangunan sebagai display barang dagangannya dan tempat pot yang tersedia digunakan sebagai tempat duduk-duduk oleh pegawai toko disamping sebagai diplay barang juga

4. Dari aktivitas pejalan kaki pada kawasan ini, di mana jenis pedestrian yang ada pada zona komersial ini adalah pedestrian arcade dimana memberikan akses langsung kepada fungsi bangunan dan aktivitas pejalan kaki pada kawasan ini menjadi lebih nyaman karena terlindung dari panasnya sinar matahari

5. Dengan tidak memilikinya set back bangunan pada kawasan komersial I ini para pengunjung lebih memilih parkir langsung pada badan jalan dengan mempertimbangkan akses langsung menuju toko dengan komoditas yang dipilihya, ini menimbulkan On street parking disepanjang kawasan yang menyebakan kemacetan pada ruas jalan Gajah mada

6. Dari vegetasi pengaruh terhadap aktivitas yang ada pada penggal 1 zona komersial tidak terlalu berdampak signifikan karena aktivitas PKL yang berada pada ruang jalan pada zona komersial ini dilakukan pada malam hari,

\section{Kesimpulan}

\section{Messo Kawasan}

Magnet kawasan yang berada pada kawasan zona budaya menjadi faktor yang berpengaruh terhadap"daya hidup" fungsi kawasan dimana kawasan zona budaya ini terletak diantara zona komersial I dan Komersial II yang menyebabkan tidak seimbangnya daya hidup fungsi kawasan di kawasan Jalan Gajah Mada Denpasar.aktivitas kawasan pada zona budaya berlangsung 24 jam. ini disebabkan oleh aktivitas PKL yang berada pada selatan ruang jalan yang berjualan sesaji banten, dan perlengkapan sembahyang umat hindu yang menjadi kebutuhan setiap hari, dan Pasar badung yang menjadi pilar dan yang menjadi salah satu pasar terbesar dikota denpasar

\section{Mikro Kawasan}

\section{a. Bangunan}

- Set Back bangunan

pada zona kawasan komersial I, II dan budaya yang tidak memiliki set back bangunan, ini mengakibatkan aktivitas PKL sesaji, janur, canang menggelar dan menjajakan komoditas dagangannya dengan memanfaatkan ruang jalan sebagai tempat untuk berjualan,

- Kolom Bangunan

Pada setiap bangunan pada zona komersial I dan II memiliki pilar/kolom pada muka bangunan ini mengakibatkan aktivitas yang terjadi para pemilik toko memanfaatkan kolom pada bangunan itu sebagai display barang dagangannya,

- Windows Shopping

tidak adanya windows shopping pada setiap toko pada kawasan Komersial I dan Komersial II, sehingga pengunjung lebih konsentrasi kepada barang yang akan mereka cari dan mengabaikan jalur pedestrian dengan menggunakan ruang jalan sebagai alternatif jalur pedestrian, dengan memperhitungkan kecepatan tiba di toko tujuan

\section{b. Jalur Pedestrian}

jalur pedestrian yang berupa arcade, dan dengan lebar jalur pedestrian $1.2 \mathrm{~m}$, kondisi dari permukaan setiap jalur pedestrian di depan toko berbeda ketinggian dan dengan setiap toko men display barang dagangannya pada depan sisi toko tepat pada jalur pedestrian arcade ini menyebabkan setiap pejalan kaki pada area komersial I ini menggunakan ruang jalan sebagai alternatif untuk menelusuri,area pertokoan,sedangkan pada malam hari Aktivitas pada pedestrian Arcade ini tidak ada, para PKL lebih memilih berjualan pada ruang-ruang 
jalan karena pada jalur pedestrian ukurannya sempit yaitu $1,2 \mathrm{~m}$ dan tidak ada penerangan pada jalur pedestrian pada malam harinya

\section{c.Tempat Parkir}

tempat parkir mempengaruhi lalu lintas kendaraan, pejalan kaki dan tukang parkir. semakin banyak kendaraan yang parkir pada bahu jalan pada jam-jam sibuk antara jam 06.00 WITA- 08.00 WITA, jam 11.30 WITA-13.00 Wita dan jam 16.3018.00 WITA arus kendaraan pada kawasan Gajah mada macet total sedangkan pengaruh bagi pejalan kaki yang berjalan ditrotoar lebih leluasa berjalan pada ruang jalan di mana berjalan di belakang parkir mobil. Semakin sedikit kendaraan yang parkir selain pada jam-jam sibuk diatas, pengguna kendaraan semakin lancar dalam melewati kawasan Gajah mada

\section{d. Vegetasi}

vegetasi pada kawasan zona budaya mempengaruhi keberadaan aktivitas PKL, dan tukang parkir serta para supir-supir pembawa barang-barang sedangkan pada zona komersial I dan II aktivitas PKL di mulai pada malam hari karena pada siang hari dan pagi hari vegetasi peneduh pada kawasan ini tidak ada

\section{e. Street Furniture}

pada elemen street furniture khususnya lampu penerangan jalan pada kawasan zona komersial I dan II sangat berpengaruh terhadap daya hidup fungsi kawasan terutama pada malam hari, aktivitas yang berlangsung padat hanya berada pada titik-titik spot yang memiliki penerangan jalan dan tempat yang nyaman ini menyebabkan kontribusi kepada fungsi bangunan sebagai elemen pendukung aktivitas pada fungsi- fungsi bangunan sangat kurang

\section{Rekomendasi}

\section{Messo Kawasan}

pentingnya keseimbangan kawasan yang dapat memecah kepadatan trafic, kepadatan aktivitas yang dapat menyebabkan konsentrasi memusat dengan memberikan magnet-magnet kawasan baru pada zona komersial I dan komersial II sebagai generator penggerak kawasan, pemberian magnet-magnet kawasan berupa pemberian tematema yang menarik para pengunjung dengan wisata kuliner disepanjang kawasan zona komersial I dan komersial II pada malam harinya, dan dalam periode waktu tertentu diadakan kegiatan eksebisi, karnaval dan festival( yang bersifat temporal).

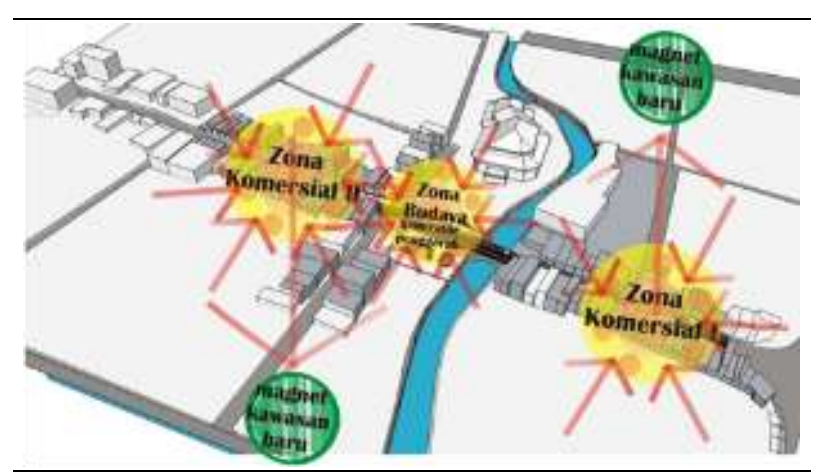

\section{Gambar 14.}

Dengan memberikan ruang-ruang transisi pada setiap zona kawasan yang dapat memecah konsentrasi aktivitas pada zona budaya, diharapkan pada zona-zona transisi dapat menjadi sebuah magnet baru yang dapat mereduksi dan dekonsentrasi aktivitas kawsan yang sebelumnya berada pada zona kawasan budaya, dengan memberikan suatu pemberian fungsi-fungsi entertainment kawasan dan komoditas perdagangan yang baru

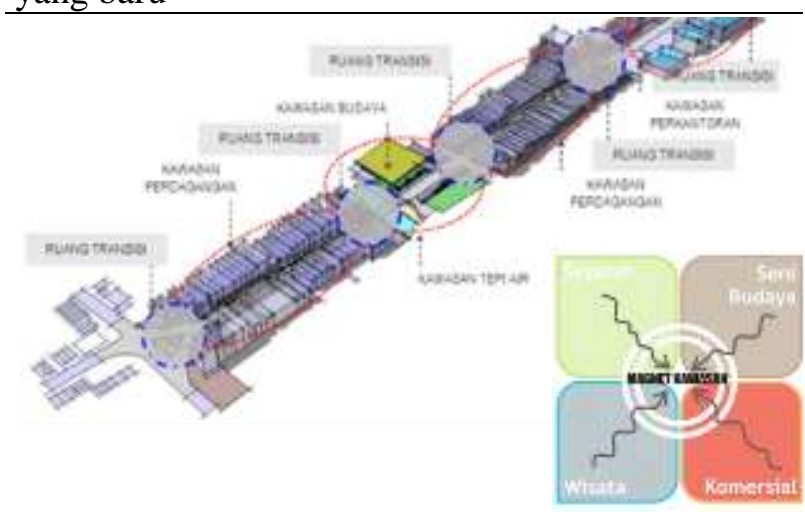

\section{Gambar 15.}

Konsep pengembangan dari kawasan Jalan Gajah Mada Denpasar dan kawasan zona-zona yang mendukung disekitarnya dengan mensinergikan hal-hal yang baru yaitu potensi sejarah dari elemen fisikny itu sendiri, seni,budaya adat istiadat masyarakat tradisional bali, wisata dan komersialnya menjadi bagian dari civic centre yang nantinya memiliki interaksi unik dan atraktif antara elemen fisik dengan elemen aktivitas yang berada dalam satu kesatuan kesinambungan arsitektur tradisional, baik itu tata letak, tata nilai, tata guna,

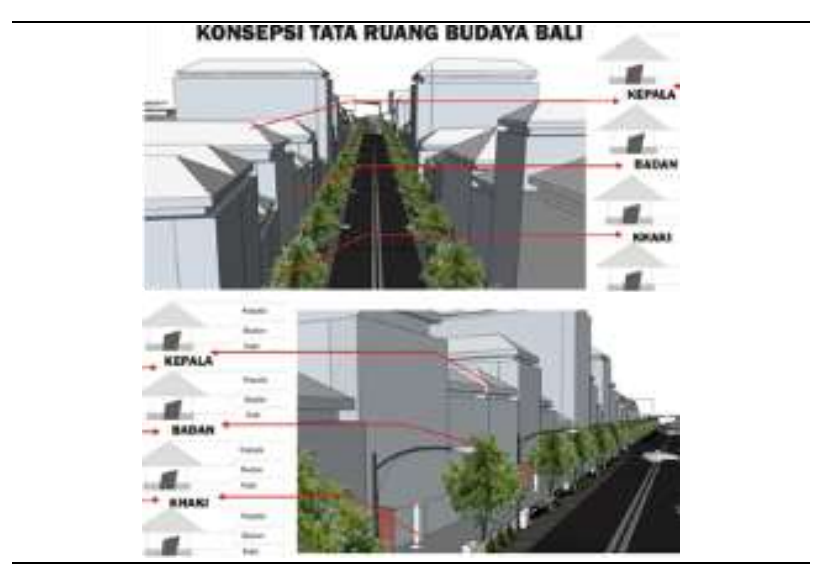

Gambar 16. 
Dengan membuat sebuah guideline, bahwa setiap bangunan yang berada pada kawasan Gajah mada harus menerapkan konsepsi tri anggadi mana terdapat kepala, badan dan kaki

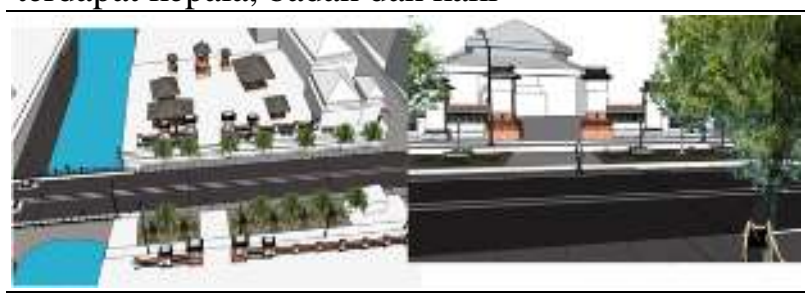

\section{Gambar 17 .}

Mempertegas tema budaya Pada Kawasan zona budaya untuk meningkatkan kondisi dan peranan kawasan Pura Desa Denpasar dan Pasar Badung sebagai kawasan budaya yang dapat dimanfaatkan masyarakat kota untuk kegiatan keagamaan, rekreasi, pelestarian kebudayaan. dalam upaya mencapai tujuan diatas, upaya menyatukan kesan kawasan merupakan hal pertama yang perlu dilakukan sehingga bangunan yang ada disekitar kawasan memiliki kesan menyatu satu dengan lainnya. Upaya ini dilakukan dengan penataan jalan dan pendestrian yaitu dengan memberikan bahan yang hampir sama antara jalan dan pendestrian serta membatasi kendaraan yang melalui jalur ini. Pemavingan jalan seperti halnya dengan pendestrian dilakukan sebagai salah satu upaya ini.

Sementara itu untuk meningkatkan fungsi Pura Desa Adat sebagai tempat suci, upaya penataan di areal depan pura perlu dilakukan dan upaya untuk menjadikan beberapa pertokoan yang ada di timur pura yang berhimpitan sebagai jaba sisi dengan melakukan relokasi terhadap toko-toko tersebut.

\section{Mikro Kawasan}

Dengan memberikan alternatif pada kawasan jalur jalan Gajah mada seperti Umbrella disetiap Zonazona transisi yang nantinya dapat berkembang sebagai Bazar aktivitas komersial yang memiliki tema-tema tertentu sesuai dengan event yang dilaksanakan pada kawasan Gajah mada, disampin sebagai penampung luberan Aktivitas PKL yang ada, Umbrella ini berfungsi sebagai penampung air hujan dan daya serap tenaga surya, yang nantinya dapat digunakan oleh Pemerintah maupun masyarakat disekitar untuk sebesarbesarnya daya hidup bagi fungsi kawasan jalan Gajah mada

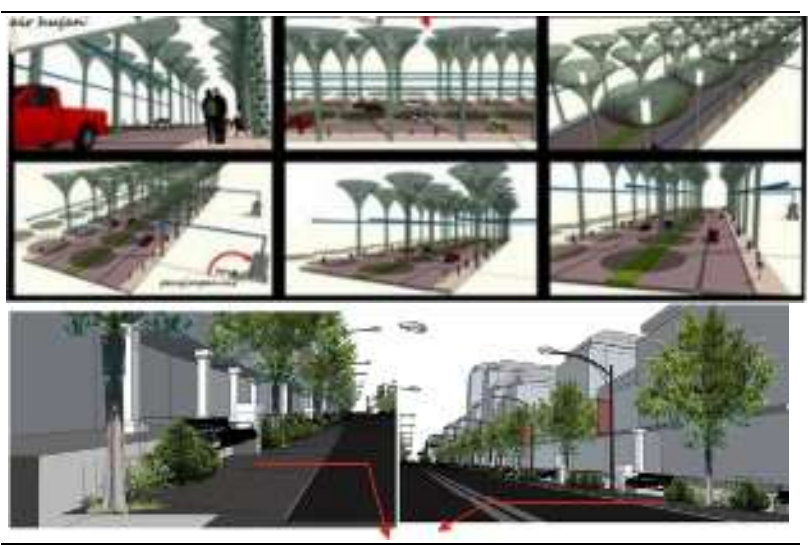

Gambar 18.

Penambahan set front dari jalur pedestrian sekitar $1,2 \mathrm{~m}$ sebagai area istirahat bagi pejalan kaki,di mana pada area ini perletakan street furniture di pasang dan tersusun secara serial dan terkomunikasikan dengan pola yang teratur dan terintegrasi pada kawasan komersial dan budaya serta efektivitas untuk menampung para PKL di malam hari dengan sebisa mungkin meletakkan dan memberi level ketinggian pada ruang jalan pada kawasan komersial

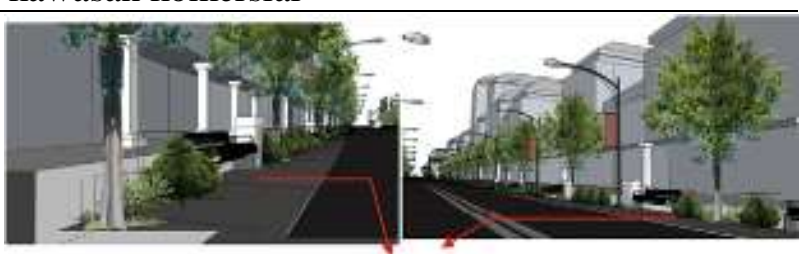

Gambar 19.

Pemberian dan pengadaan street furniture terutama penerangan lampu jalan di pemberian dan pengadaan street furniture terutama penerangan lampu jalan di mana aktivitas yang terjadi pada ruang jalan oleh PKL berkumpulnya pada titik-titik yang memiliki penerangan jalan yang baik dan dekat dengan magnet kawasan yang ada, street furniture merupakan elemen yang sangat penting pada zona komersial kawasan jalan Gajah mada dalam menggerakkan daya hidup dan perekonomian sebuah kawasan

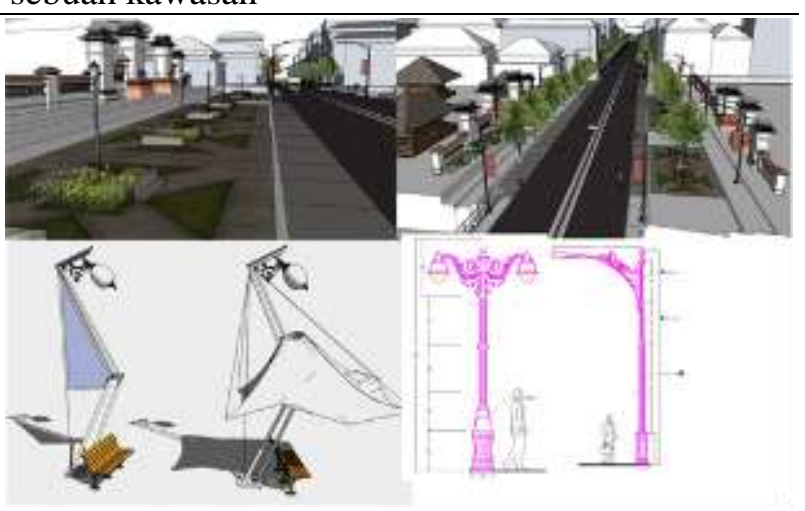

Gambar 20.

Pemberian dan pengadaan street furniture terutama penerangan lampu jalan di mana aktivitas yang terjadi pada ruang jalan oleh PKL berkumpulnya pada titik-titik yang memiliki penerangan jalan yang baik dan dekat dengan magnet kawasan yang ada, street furniture merupakan elemen yang sangat penting pada zona komersial kawasan jalan Gajah mada dalam 
menggerakkan daya hidup dan perekonomian sebuah kawasan

\section{Daftar Pustaka}

Agung, Ida Cokorda Ngurah. "Lintasan Babad Badung”. Tulisan yang belum diterbitkan.

Anonim. 2003. Petunjuk Penulisan Usulan Penelitian dan Tesis. Universitas Gajah Mada, Yogyakarta.

Arifin, E. Zaenal. 2006. Dasar-dasar Penulisan Ilmiah. Jakarta: PT Grafindo.

Ashihara, Yoshinobu. 1986. Merencana Ruang dalam. Terjemahan S. Gunardi, FTA. Institut Teknologi Surabaya, Surabaya

Baso Thamrin,1997. Karakter Pedagang Kaki Lima, Jurnal Hi-tech, Edisi 04

Budihardjo, Eko, 1997, Jati diri Arsitektur Indonesia, Penerbit Alumni Bandung, Bandung.

Budihardjo, Eko, 1997, Tata Ruang Perkotaan, Penerbit Alumni Bandung, Bandung.

Budiharjo, Eko, Arsitektur Pembangunan dan Konservasi, Penerbit Djambatan, Jakarta, 1997.

Hakim Rustam ,1984. Unsur-Unsur Perancangan Arsitektur Lanskap, Bina Aksara, Jakarta

Haryadi, B. Setiawan, 1995. Arsitektur Lingkungan dan Perilaku.Proyek Pengembangan Pusat Studi Lingkungan. Direktoral Jenderal Pendidikan Tinggi dan kebudayaan, Republik Indonesia.

Hatmoko, Adi U.1999. Hand Out. Perancangan Kawasan Perkotaan (Urban Design) Fakultas Teknik UGM, Yogyakarta.

H.B Sutopo. 2002. Metodelogi Penelitian Kualitatif. UNS Press Solo

Ikaputra. 2002. "Ruang Publik Kota Untuk Siapa "Jakarta: Kompas, 19 mei 2002. " "Denpasar as Administrative Centre ", Makalah disampaikan pada International Workshop "Bali Modernity Project Wollongong Workshop" 10-11 July 1995.

. „Labour Workers Movement in Bali in the Twentieth Century "Paper dipresentasikan pada International Workshop, "Reconstructing the Historical Tradition of Twentieth Century Indonesian Labour", pada tanggal 4-6 Desember 2001, Bali Indonesia.

Pengembangan Industri Pariwisata Berbasiskan Budaya Lokal di
Ching, Francis D.K. 2000. Arsitektur Bentuk, Ruang, dan Tatanan. Jakarta: Erlangga.

Departemen Permukiman dan Prasarana Wilayah; Direktorat Jenderal Tata Perkotaan dan Tata Perdesaan, Pengantar Revitalisasi Kawasan Bersejarah, 1996/1997.

Denpasar, 1983. Koleksi Puri Satria, Denpasar.

Dinas Tata Kota dan tata bangunan, Pemerintah Kota Denpasar; Penyusunan DED Rencana Teknis Pusat Kota (Peraturan Zonasi Kawasan Pusat Kota)

Dinas Tata Kota dan tata bangunan, Pemerintah Kota Denpasar; Penyusunan Rencana Penataan koridor Jalan Gajah Mada

Emelianti,2001, Ruang Jalan Sebagai Wadah Aktivitas pada kampong Kota, Jurnal Arsitektur Tatanan Vol.2 No 4, Bandung

Gomudha, I Wayan, 1998, Pernik Manik Spasial Hunian Arsitektur Tradisional Bali, Program Studi Arsitektur Program pasca Sarjana Institut Teknologi Sepuluh Nopember, Surabaya.

Hariyono, Paulus. 2007. Sosiologi Kota Untuk Arsitek. Jakarta: Bumi Aksara.

Munandi, Agus Aris. 1998. Architecture. Singapore: Archipelago Press.

Bali. Jakarta: Pusat Penelitian Kemasyarakatan dan Kebudayaan-LIPI, 2002.

Jakarta: Research Center for Regional Resources, the Indonesian Institute of Sciences, 2003.

Sumalyo, Yulianto, Arsitektur Kolonial Belanda di Indonesia, Gajah Mada University Press, 1995.

Susila Patra, Made, 1992, Hubungan Seni Bangunan Dengan Hiasan Dalam Rumah Tinggal Adati Bali, Balai Pustaka.

Zahnd, Markus, Perancangan Kota Secara Terpadu; Teori Perancangan Kota dan Penerapannya, Penerbit Kanisius, Yogyakarta, 1999.

"Denpasar, Kota Tanpa Urban Design", dalam Koran Pak Oles, 59, I, Juni 2004.

Gist, N. P dan S. F. Fava, Urban Society. New York, 1964.

"Masalah Parkir Sangat Kompleks", dalam Koran Pak Oles, 59, I, Juni 2004.

"Multikultur Kota Denpasar: Penampilan Fisik Minus Cerminan Budaya", dalam Bali Post, 21 Februari 2004. 